\title{
HOMONYMY NOTE IN MUSCIDAE (DIPTERA) ${ }^{1}$
}

\author{
Márcia Souto Couri ${ }^{2}$ \\ Claudio José Barros de Carvalho ${ }^{3}$
}

\begin{abstract}
The following new name is proposed for Hypsomyia Couri \& Carvalho (Diptera, Coenosiinae, Limnophorini): Albertinella n.nov.

KEY WORDS. Muscidae, Albertinella n.nov., homonymy, Hypsomyia
\end{abstract}

COURI \& CARVAlHo (1994) described Hypsomyia for a new species of Muscidae, Coenosiinae, Limnophorini from Pico da Neblina, Amazonas, Brazil. As Hypsomyia is preoccupied by CORTÉs $(1983: 380,382)$ in the family Tachinidae (Diptera), the following new name: Albertinella, new name for Hypsomyia Couri \& Carvalho, 1994, with one species: Albertinella nebulicola (Couri \& Carvalho, 1994), is proposed.

ACKNOWLEDGMENTS. The authors are grateful to Mrs. Joan Thorne (Editorial Manager, Biosis, U.K.) who alerted us for this homonyny.

\section{REFERENCES}

CoRTÉs, R. 1983. Tachinid flies (Diptera, Tachinidae) from Tarapaca and Antofagasta Provinces, Chile. 3. Addendum. Florida Ent. 66 (4): 377-389.

COURI, M.S. \& C.J.B. DE CARVALHO. 1994. Hypsomyia nebulicola gen.n., sp.n. de Limonphorini do Pico da Neblina, Brazil (Diptera, Muscidae, Coenosiinae). Rev. Brasil. Biol. 54 (4): 569-573.

Recebido em 21.VI.1996; aceito em 28.XII.1996.

1) Contribution number 954 of the Departamento de Zoologia, Universidade Federal do Paraná.

2) Museu Nacional, Universidade Federal do Rio de Janeiro. Quinta da Boa Vista, São Cristóvão, 20940-040 Rio de Janeiro, Rio de Janeiro, Brasil. Fellow of the CNPq.

E-mail: mcourimn@omega.Incc.br.

3) Departamento de Zoologia, Universidade Federal do Paraná. Caixa Postal 19020, 81531-990 Curitiba, Paraná, Brasil. Fellow of the CNPq.

E-mail: cjbcarva@bio.ufpr.br. 